\title{
The aflatoxin content of milk and dairy products as well as breast milk and the possibilities of detoxification
}

\author{
J. Csapó ${ }^{1,2}$ \\ Cs. Albert ${ }^{2}$ \\ e-mail: csapo.janos@gmail.hu \\ e-mail: albertcsilla@uni.sapientia.ro
}

\author{
P. Sipos $^{1}$ \\ e-mail: siposp@agr.unideb.hu
}

${ }^{1}$ University of Debrecen, Faculty of Agricultural and Food Sciences and Environmental Management, Institute of Food Technology, HU-4032 Debrecen, 138 Böszörményi St.

${ }^{2}$ Sapientia Hungarian University of Transylvania (Cluj-Napoca, Romania), Faculty of Economics, Socio-Human Sciences and Engineering, Department of Food Science, RO-530104 Miercurea Ciuc, 1 Libertıaţii Sq.

\begin{abstract}
Aflatoxins are fungal toxins produced by Aspergillus species, which, due to increasing temperature and climate change in the temperate zone, appeared in the most important feeding plant and food ingredients. The most toxic of them is aflatoxin B1 (AFB1), which hydroxylates to aflatoxin M1 in the body of dairy animals and humans, and excretes in the milk. With the development of analytical methods, researchers are now able to detect toxins with a concentration of $\mathrm{ng} / \mathrm{kg}$. It was found that in most countries in Europe both breast milk and cow's milk may contain AFM1, and therefore increased attention should be paid to the toxin content of milk, and that those above the limit should be excluded from consumption. In addition to cow's milk, the AFM1 toxin content
\end{abstract}

Keywords and phrases: mycotoxins, aflatoxins, aflatoxin M1, milk, breast milk, detoxification of mycotoxins, determination of aflatoxins 
of breast milk can also be significant, the precursors of which are introduced into the mother's body with food. Aflatoxins are highly resistant to physical, chemical, and microbiological effects, so the detoxification of foods, especially milk, is almost impossible. The best solution appears to be feeding the animals with toxin-free feeds or feeds containing toxins below the permitted limit, without giving opportunity to the toxins to enter the milk from the feed and from there into the human body.

\section{Introduction}

Aflatoxins are one of the main classes of mycotoxins, being secondary products of metabolism of microscopic fungi such as Aspergillus flavus, Aspergillus parasiticus, or Aspergillus nomius (Creppy, 2002). The main classes of aflatoxins are aflatoxin B1 (AFB1), aflatoxin B2 (AFB2), aflatoxin G1 (AFG1), and aflatoxin G2 (AFG2). Conditions such as drought, high temperatures, substrate composition, and storage time play a very important role both in the growth of fungi and in the production of toxins. Of the toxins listed, AFB1 has the most toxic, carcinogenic, teratogenic, and mutagenic effects (Sweeney \& Dobson, 1999).

Aflatoxins are colourless, pale yellow crystalline compounds that fluoresce in ultraviolet (UV) light. They dissolve only slightly in water $(10-20 \mu \mathrm{g} / \mathrm{mL})$ but are well dissolved in slightly polar solvents such as chloroform or dimethyl sulphoxide. UV light breaks it down in the presence of oxygen and is unstable even below $\mathrm{pH}=3$ or above 10 . The lactone ring splits in a reversible reaction under alkaline conditions but may re-form under the influence of acid. At high temperatures in an irreversible reaction and after decarboxylation, ammonia also splits the lactone ring (Kumar, 2018).

AFB1 shows absorption maximum at 223, 265, and 362, AFB2 at 265 and 363, AFG1 at 243, 257, 264, and 362, and AFG2 at 265 and $363 \mathrm{~nm}$. AFB1 occurs in almost all foods, and its hydroxylated derivative, aflatoxin M1 (AFM1), is also found in milk and dairy products as well as in breast milk. In addition to milk, it has also been shown in cheeses, ice cream, and yoghurt. In particular, a lot of AF may be contained in fat-rich milk and dairy products, and especially a lot of AF is accumulated in butter thanks to the high volume of apolar triglyceride content (Kumar, 2018).

The AFM1 is the hydroxylated metabolite of AFB1, which is excreted through milk in humans and dairy animals (Fallah et al., 2009). Approximately 0.3-6.2\% of AFB1 is transformed to AFM1 by the genetics of the animals, season, type of milk production, and environmental factors. The toxic effect of 
AFM1 is much less than that of AFG1; however, it causes health problems because in many countries the milk and dairy products are a significant part of daily food, and so the toxin can enter the body of many people not only with milk but also with dairy products (Unusan, 2006; Fallah et al., 2009).

Symptoms of acute toxicity in mammals include the development of lethargy, loss of appetite, rough or halo hairs, ataxia, and fatty liver. In animals, jaundice may develop, feed is rejected, and milk production is significantly reduced. Aflatoxins reduce disease resistance and inhibit immunity developed by vaccines (Diekman \& Green, 1992). In beef cattle, the $700 \mu \mathrm{g} / \mathrm{kg}$ toxin volume did not reduce mass gain, but, since the liver has increased significantly, it is considered that the toxin content of the feed should not exceed $100 \mu \mathrm{g} / \mathrm{kg}$. In dairy cows, this amount has already significantly increased the concentration of aflatoxin in the milk. It has been reported that feed containing $120 \mu \mathrm{g} / \mathrm{kg}$ toxins decreased significantly the reproduction, and when the cows were fed with a feed that did not contain toxins, milk production increased by $25 \%$. Milk production decreased more when cows took the toxin with contaminated feed than when it was added to feed in synthetic form (Guthrie, 1979; Patterson \& Anderson, 1982).

\section{How to prevent toxins from entering the milk?}

Today, Aspergillus species, which are capable of producing aflatoxins due to the rising global average temperature and climate change, have also appeared in temperate zone environments, such as in Hungary, and the toxins can be found in the different food and basic feed materials such as maize or wheat. The most toxic of them is aflatoxin B1, which, absorbed from feed, is able to form an aflatoxin M1 in the bovine body, which reaches the milk gland during milk production and is excreted with the milk.

Milk is one of the most important basic foods, whose production is estimated to double by 2050 to provide the growing population with the necessary nutrients. It is very important that milk does not contain AFM1 at all or only to an acceptable degree because otherwise this important food material can become a source of toxic materials (Iqbal et al., 2015).

According to the Food and Feed Safety Administration of the National Food Chain Safety Office of Hungary (NÉBIH), the most important is to ensure that cattle are treated with feeding stuffs with the lowest possible contamination and low aflatoxin content because the toxin is introduced through the feed into the blood through the cattle's digestive tract and from there into the 
milk. In Hungary, due to the changed climatic conditions, aflatoxins have also appeared in maize, which are the main source of contamination (Szeitzné Szabó \& Frecskané Csáki, 2013).

When feeding with contaminated feed, the toxin appears in the milk within up to a day, and for the depletion of the toxin, when feeding toxin-free or low-toxin-content feed, it is necessary to wait two to three days. In the case of basic feed materials, the maximum permissible limit for aflatoxin B1 is 20 $\mu \mathrm{g} / \mathrm{kg}$, but this is lower, $5 \mu \mathrm{g} / \mathrm{kg}$, for feed mixtures of dairy cows. In the case of milk, the maximum amount of toxin is $50 \mathrm{ng} / \mathrm{kg}$, and milk with a higher toxin content cannot be released in Hungary (Szeitzné Szabó \& Frecskané Csáki, 2013).

In Hungary, the sources of pollution are feed mixtures made from byproducts of grain maize and maize processing. The most important means of preventing the AFB1 contamination of milk is the feeding of toxin-free or low-toxin-content feed to dairy cows. If the toxin content of the feed is known, feeding feed with a toxin content exceeding the limit value can be prevented, or the feed formula can be assembled in such a way that its toxin content falls below the limit value.

If the feed of dairy cows is contaminated with AFB1, the toxin is hydroxylated in the bovine body and enters into the milk in the form of aflatoxin M1. Toxin absorption from feed varies per person, and the lactation status of the individual and the milk yield also influence it. In cows with low milk yields, $1-2 \%$ of the toxin and with high milk yields $5-6 \%$ of the toxin enters into the milk, and more toxins are excreted at the beginning of lactation since in fresh-milk cows, under the same toxin load, the toxin content of the milk may be three to four times higher than at a later stage of lactation. As a result, the toxin content of milk may be above the limit value even if cows still consume feed with the permitted concentration of toxins. In general, however, it can be stated that the toxin content of milk remains at the permitted level if cows do not take more than $40 \mu \mathrm{g}$ of toxins per day (Szeitzné Szabó \& Frecskáné Csáki, 2013).

The toxin content of milk may also be affected by the physiological state of the animal since if the $\mathrm{pH}$ of the rumen is reduced (rumen acidosis), the effectiveness of the absorption of the toxin can also increase several times. If the toxin content of the milk is nevertheless above the permitted limit, an immediate replacement of the feeding stuffs may be required, or toxin bindings may be used, which may reduce the toxin content of the milk by $20-30 \%$. The use of toxin binders is only an emergency solution; the final result can only be obtained by feeding toxin-free or low-toxin feeds. Attention is drawn to 
the analysis of the toxin content of feed carried out in accredited laboratories, because the toxin content of milk can be estimated from the concentration of the toxin and the amount of the fed feed (Szeitzné Szabó \& Frecskáné Csáki, 2013).

The AFM1 in milk, especially coupled to casein, can be found in the aqueous phase, and so the AFM1 content of cream and butter is relatively low. During cottage cheese and cheese making, most of the toxin is transferred to the curd, and only a smaller part of it is left in the whey; so, the AFM1 concentration of soft cheeses is about three times and of hard cheeses five times higher than the toxin concentration of the milk used as a raw material (Szeitzné Szabó \& Frecskáné Csáki, 2013).

\section{Stability of AFM1 and the possibility of reduction in milk and milk products}

AFM1 is very stable at high temperatures, so, during normal heat treatment methods, it does not suffer significant decomposition in milk. Many researchers have also studied the stability and the changes in the composition of dairy products and how much AFM1 of milk passes into the dairy product. AFM1 was stable in Kashar cheese even after the 60-day maturation period and had an unchanged concentration in traditional cheeses during 90 days of maturation (Oruc et al., 2006).

When assessing the stability of AFM1 in artificially contaminated yoghurt, it was found that the volume of either at concentrations of 0.05 or $0.10 \mu \mathrm{g} / \mathrm{L}$ during four-week storage, $\mathrm{pH}=4.6$ did not change, but if $\mathrm{pH}$ was reduced to 4.0, the volume of both concentrations decreased significantly by the end of the third and fourth week. In a similar experiment, the AFM1 amount of yoghurt decreased significantly during the production and storage of yoghurt. The decrease is attributed to low $\mathrm{pH}$, to the effect of organic acids and fermentation by-products, and to the presence of lactic acid bacteria (Govaris et al., 2002). In another experiment, $13 \%$ more AFM1 was found in yoghurt than in the starting milk, but the difference was not significant (Bakirci, 2001).

When making Ricotta cheese, 94\% of AFM1 remained in the liquid phase, and only $6 \%$ were included in the cheese. When ultrafiltration was used, almost $90 \%$ of AFM1 remained in the liquid phase, and only a minimum quantity was transferred to the cheese. Spray drying also decreased the amount of AFM1 in significant quantities (40-60\%) (Cattaneo et al., 2013).

During UHT heat treatment, different technologies use temperatures of 130- 
$150{ }^{\circ} \mathrm{C}$ and different heat maintenance periods, so the results of the degradation of AFM1 to heat are also contradictory. Some (Purchase, 1967; Kabak \& Ozbey, 2012) reported of about $32 \%$ decrease, while others (Galvano et al., 1996) claimed that at this temperature the AFM1 is heat stable, and its concentration is not affected by UHT treatment. Looking at the effect of different technologies in UHT treatment, it was found that decomposition was 12-35\% depending on the circumstances, but in most cases it was also found that heat treatment had no effect on the concentration of AFM1 (Prandini et al., 2009).

Several researchers experimented with reducing the AFM1 content of cow's milk and dairy products by the use of clay and clay minerals (Carraro et al., 2014). These studies have shown that benthonic is very effective in reducing the AFM1 content of cow's milk if its concentration has not exceeded 80 $\mathrm{ng} / \mathrm{L}$. The concentration was reduced to $50 \mathrm{ng} / \mathrm{L}$ for adults and to $25 \mathrm{ng} / \mathrm{L}$ for children without significantly altering the organoleptic properties of milk.

Among the cultures used in the production of yoghurt, Streptococcus thermophilus, Lactobacillus bulgaricus, and Lactobacillus plantarum were the most effective at reducing AFM1 levels during the storage of yoghurt (Elsanhoty et al., 2014). Using probiotic strains, the concentration of AFM1 was reduced by $19.9-25.4 \%$, and in in vitro trials with probiotic strains, depending on its type, they were able to achieve a decrease of 23-45\% (Serrano-Nino et al., 2013).

In rare cases, the concentration of AFM1 in dairy products exceeds $1 \mu \mathrm{g}$ per litre. The AFM1 content of cheeses is not produced during fermentation, but it comes from milk, and the milk is obtained through the feed consumed by the animal. AFB1 absorbed from feed is converted into AFM1 in the liver and is found in almost all dairy products.

Since cows also consume a lot of imported nutrients, the toxin can also be found in milk even if the basic foodstuffs are toxin-free. AFM1 is stable both during heat treatment and other cheese-making processes, and its concentration does not change when stored. The detoxification of AFM1, without damaging the valuable components of food, is almost impossible (Tabata, 1998).

Milk and dairy products can be contaminated with mycotoxins in an indirect and direct manner. The easiest way to indirect contamination is to eat feed infected with microscopic fungi. AFM1 has the greatest importance, which is the main metabolite of AFB1. The effect of AFM1 on the human body is virtually the same as that of AFB1. Direct contamination occurs when, for example, moulds proliferate in the inside or on the surface of cheeses, which are capable of producing toxins. These can even be components of the 
starter cultures used to make different cheeses. Aspergillus strains can infect even milk or dairy products, after which they produce a toxin AFB1, whose concentration is generally much smaller than that of AFM1 (Fisher et al., 2011).

AFB1, which is added to the body with food, is converted there to AFM1, which is either excreted in urine or reaches the foetus through the placenta during pregnancy, and so the new generation already encounters the toxin in intrauterine life or is excreted with breast milk and with it enters the newborn's body. Aflatoxins are found in a lot of basic food and feed materials and are thus introduced directly or through the animal, e.g. with milk, and get into the human body.

During 2013-2014, 80 milk samples and 21 infant formulas have been examined with the AFM1 content. It was found that its concentration varied from 0.02 to $0.32 \mu \mathrm{g} / \mathrm{kg}$, and the mean value was $0.13 \mu \mathrm{g} / \mathrm{kg}$. In $75 \%$ of the samples, the AFM1 concentration exceeded the $0.05 \mu \mathrm{g} / \mathrm{kg}$, which is considered by the EU as a limit. On the basis of the results, the levels of toxins that may be consumed by each animal species as well as the types of exploitation have been determined. The lowest value, $0.05 \mu \mathrm{g} / \mathrm{kg}$ AFM1, was determined for dairy animals (Spanjer, 2018).

\section{Aflatoxin content of breast milk}

In recent times, sensitive methods for determination of the concentration of aflatoxins and their metabolites have been developed, with LOD (limit of detection) valued at 3-6 ng $/ \mathrm{kg}$, with the help of which the small toxin content of breast milk can also be measured. During the experiments conducted in Germany, they were unable to detect AFM1 neither in the 120 samples collected from Kiel nor in the 75 samples from Munich. By contrast, for Sudanese sam-

ples from the same time, $75 \%$ were tested positive, and $11 \%$ of the Zimbabwean samples showed positive results, with a maximum value of $51 \mathrm{ng} / \mathrm{L}$ (Coulter et al., 1984). All the 42 French samples produced negative results, and in Italy $1-5 \%$ of the samples were positive, but the maximum value reached nowhere the $200 \mathrm{ng} / \mathrm{L}$ level (Galvano et al., 2008; Turconi et al., 2004).

The situation is much worse in Africa, where mainly AFB1 and AFM1 toxins have been detected in breast milk. In Ghana $32 \%$, in Kenya $28 \%$, in Nigeria $12 \%$, and in Sudan $37 \%$ of the investigated samples were positive, where the maximum amount of toxins reached the level of a few $\mu \mathrm{g}$ per litre. These results show that babies in African countries have access to aflatoxins in significant 
quantities with breast milk, and some consume very serious amounts. In the town of Bishoftu, Ethiopia, of the 108 milk samples analysed for AFM1, all samples were found to be contaminated $(100 \%)$ with a mean value of 0.835 $\mu \mathrm{g} / \mathrm{l}$. The highest AFM1 content was $2,159 \mu \mathrm{g} / \mathrm{l}$ and the lowest was 0.029 $\mu \mathrm{g} / \mathrm{l}$; both were obtained from the local milk producers (Tadesse et al., 2020). The situation in some Arab countries is not much better either. In Egypt, approximately $50 \%$ of the tested samples were positive, and the amount of the toxin varied from 4 to $120 \mathrm{ng} / \mathrm{L}$, but in some cases it reached a level of 19 $\mu \mathrm{g} / \mathrm{L}$ ( Tomerak et al., 2011).

Various studies have shown that the concentration of aflatoxin in milk shows seasonal fluctuations, which for AFM1 may be associated with the life function and production of toxins of moulds in foods consumed by mothers. According to one study, the milk of Egyptian mothers contained $13.5 \mathrm{ng} / \mathrm{L}$ AFM1, which is far less than those measured in the neighbouring countries. In Abu-Dhabi, $99.5 \%$ of the tested samples were positive, the results varied from 2 to 3,000 $\mathrm{ng} / \mathrm{L}$, and the average was $68 \mathrm{ng} / \mathrm{L}$. In the United Arab Emirates, $92 \%$ of the tested samples were positive, the results varied from 5 to $3,400 \mathrm{ng} / \mathrm{L}$, and the average was $560 \mathrm{ng} / \mathrm{L}$ (Abdulrazzag et al., 2003).

The situation is further complicated by the fact that different regions within some countries (Turkey, Iran) also show different data. Summing up, in most European countries, the load of AFM1 on infants from breast milk is negligible, but the situation may be critical for some tropical African and Middle Eastern countries. In West Africa, in the United Arab Emirates, and in Egypt, the toxin content of breast milk's AFM1 may significantly exceed the level of 25 $\mathrm{ng} / \mathrm{L}$ indicated as a top level in Europe and the United States, and, in addition, the resistance and efficiency of deactivation of newborns and infants to toxins is much lower than in adults. As a result, the growth and development of infants is reduced, which justifies the development of a strategy for a significant reduction in the toxin content of breast milk in countries at risk (Polychronaki et al., 2017; Galvano et al., 2008; Degen et al., 2013).

\section{Ways to detoxify foods contaminated with afla- toxin}

Several physical, chemical, microbiological, and biological methods have been developed to detoxify and remove aflatoxins. It is essential for these methods not to reduce the nutritious value of the food during detoxification, that the byproducts causing carcinogenesis and mutagenesis are not produced during the 
procedure, and that the method should destroy Aspergillus spores and mycelia so that they cannot produce new toxins (Santini \& Ritieni, 2013; Sowley, 2016). The first step of physical methods is the separation and removal of the contaminated food fraction, followed by detoxification with heat, cooking, roasting, or irradiation. Aflatoxins are poorly soluble in water and cannot be removed from food by washing with water, but it has been reported that washing with water has been able to extract $40 \%$ of aflatoxin from food (Hwang \& Lee, 2006).

The decomposition temperature of the various aflatoxins is between 273 and $306^{\circ} \mathrm{C}$; nevertheless, various heat treatment procedures have been developed to reduce its volume. In doing so, with cooking, roasting, frying, or hot steam, the content of aflatoxin has been reduced with a significant degree (50-70\%) (Jalili, 2015). Only minor results have been achieved with gamma irradiation, while radiolysis in aqueous medium, generating free radicals, was not successful either. The destruction of microorganisms depends on the strength of gamma radiation as microorganisms did not die at a low dose (0.1 MRad), but the dose of 0.3-0.4 MRad prevented the reproduction and toxin production of moulds (Samarajeewa et al., 1990).

The absorption of aflatoxin on a solid adsorbent surface is another opportunity for detoxification. Such adsorbents may include activated charcoal, aluminium oxide, diatomic earth, clay, bentonite and montmorillonite, zeolite and hydrated calcium aluminium silicate, polysaccharides, such as cellulose, or derivatives, such as glucomannans or peptido glycans, or synthetic polymers or their derivatives (Huwing et al., 2001). A greater effect could be achieved when these adsorbents were used in combination instead of applying them separately (Khadem et al., 2012).

Several of the chemical methods used sodium hypochlorite, chlorine dioxide or chlorine gas itself, hydrogen peroxide, ozone and sodium hydrogen sulphate for detoxification, and many used acidic or alkaline hydrolysis for the oxidation of the double bonding of the furan ring or for the oxidation or the hydrolysis of the lactone ring (Doyle et al., 1982; Samarajeeva et al., 1990; Jalili, 2015). Peroxide treatment can reduce $100 \%$ of AFM1 in milk but requires a high dose of hydrogen peroxide that may leave a residue, which is a concern for human health (Nguyen et al., 2020).

Chemicals such as $75 \%$ methanol, $5 \%$ dimethylamine hydrochloride, aldehydes, benzoyl peroxide, osmium tetroxide, iodine, copper ammonium sulphate, potassium permanganate, kinons, sodium borate, or formaldehyde were used for detoxification; however, these methods were not used in practice due to the difficult removability of residual substances (Samarajeewa et al., 1990). 
Many bacteria and fungi are also able to detoxify aflatoxins from solutions. A strain of flavobacteria was able to detoxify and completely remove AFB1 from milk, oil, peanut butter, peanuts, and wheat and was effective in soy (Ciegler et al., 1966). It has also been reported that from naturally contaminated milk, with the help of the flavobacteria, $9.9 \mu \mathrm{g} / \mathrm{mL}$ of aflatoxin could be completely removed at $30^{\circ} \mathrm{C}$ in four hours. In addition to flavobacteria, other microbes are able to degrade aflatoxin as well, and even the Tetrahymena pyriformis protozoa was able to do it (Doyle et al., 1982).

In addition, with the help of their peroxidase enzyme, the moulds themselves are able to dismantle the toxin, which creates free radicals by dismantling hydroperoxides, which can react with aflatoxins. Out of the peroxidases in the presence of hydrogen peroxide and chloride ions, the myeloperoxidase creates hypochlorite and nascent oxygen, which effectively react with aflatoxins (Wogan, 1966).

Cold plasma has been used for the degradation one of aflatoxin. Although it has never been applied for degrading AFM1 in milk, it has been used to reduce AFB1 in other food samples. The physical and chemical quality of milk following treatment with cold plasma for controlling microorganisms has shown no noticeable changes in $\mathrm{pH}$, colour, and fatty acids (Nguyen et al., 2020).

AFB1 is the most toxic one of aflatoxins and is the most common in different foods; therefore, its metabolite, AFM1, has also received a lot of attention in research studies (Iqbal et al., 2015; Van Egmond, 1989). The transformation of AFB1 into AFM1 can also be considered as a detoxification process because the carcinogenic and mutagenic effect of AFM1 is only approximately $10 \%$ of AFB1 (Wogan \& Paglialunga, 1974).

Most of the physicochemical and biological detoxification methods could lessen the concentrations of AFM1 in milk, with the apparent reduction rate ranging from 1.9 to $90.0 \%$. It is worth noting that these detoxification methods are still substandard relative to the EU limit (50 ng/L) (Min et al., 2020).

\section{Methods for determining aflatoxin M1 from milk and dairy products}

The first step in most methods is the extraction of AFM1 from milk and dairy products using a mixture of polar organic solvents such as acetonitrile, methanol, or acetone. The use of chlorinated hydrocarbons during extraction has been reduced for environmental reasons (Shephard, 2008). Most use chro- 
matographic methods to separate AFM1 from other components, preceded by steps such as sample preparation and extraction, cleaning, and perhaps derivatization. In doing so, all components that may interact with the component we are looking for during weaning must be removed from the sample. Cleaning methods include column chromatography, the use of solid-phase extraction columns, fluid-fluid extraction, the use of immunoaffinity columns and multifunctional columns applied in one step (Krska et al., 2005).

These procedures are simple, increase efficiency and speed, minimize solvent use, increase toxin release, and reduce costs. Solid-phase adsorption or the use of immunoaffinity columns reduces preparation time to a few minutes but requires preparatory steps such as conditioning the column, withholding the desirable components on the column, and then removing desirable components from the column. However, minimal interference may occur between the materials to be retained and the column load, but this preparatory operation allows small concentrations to be determined by the following chromatography methods (Fuchs et al., 2002).

After the appropriate sample preparation, most researchers used liquid chromatography methods and ELISA to determine the AFM1 content of milk and dairy products. Many of them used thin-layer chromatography, fluorimetrics, ultra-performance liquid chromatography, linked to tandem mass spectrometry, lateral flow, and gel-based immunodeterminations. High-performance liquid chromatography is also used by fluorescent detection for the AFM1 analysis of milk and dairy products (Fallah, 2010; Huang et al., 2014; Anfossi et al., 2013).

Although thin-layer chromatography is perhaps one of the oldest chromatography procedures, it has been used widely to determine AFM1, and even in 1990 the AOAC adopted it as an official method also in cases where the concentration of the toxin developed around $1 \mu \mathrm{g} / \mathrm{g}$. However, its application was reduced to HPLC fluorescent detection, especially when the latter method began to be combined with mass spectrometry or gas chromatography. In recent years, almost exclusively, both of the modifications of HPLC have been used to determine AFM1. Depending on the polarity of toxins, both normal-phase and reverse-phase chromatography were used (Iqbal et al., 2013).

In the case of milk and dairy products, depending on the type of sample, HPLC procedures are practically the same, the difference being only in the composition of the mobile phase and in the stationary phase of the column. Fluorescent detectors are also excellent for use since each toxin has its own emission and excitation maximums. Moreover, the advantage of HPLC methods is the very low detection level (LOD) and the ability to detect several 
components from a sample (Valenta, 1998).

Due to its ease of applicability, lately, the ELISA method has also become very popular for detecting AFM1. The advantage of ELISA is the ease of use, high specificity, and portability; so, it is not necessary to have a well-equipped laboratory for analysis, and a large number of samples can be analysed with it in a short period of time (Anfossi et al., 2013).

A lot of methods with biosensors have also been developed to detect the AFM content of milk. One of them is such a membrane-based flow system where the antibody against AFM1 is linked to the horseradish peroxidase enzyme. This indirect, visually assessable mobile biosensor can measure AFM1 in 18 minutes with a concentration of $0.05 \mathrm{ng} / \mathrm{mL}$. The LOD value of an impedimetric biosensor developed for AFB1 for milk samples is $0.1 \mathrm{ng} / \mathrm{mL}$. A manual biosensor, based on immunoaffinity and linked to fluorometric detection, can measure AFM1 in less than two minutes with a concentration of 0.1 $\mathrm{ng} / \mathrm{mL}$ (Rasooly \& Harold, 2011).

\section{Conclusions}

With the rise of global mean temperature and climate change, conditions in the temperate zone have become optimal for the spread of Aspergillus species, which under certain circumstances are capable for the production of mutagenic, teratogenic, and carcinogenic toxins such as AFB1, AFB2, AFG1, and AFG2. AFB1 is incorporated into the body of the mother or dairy animals, where it is hydroxylated during a process considered as a detoxification step, and then it is excreted in the milk from where it enters the body of the infants or adults. AFB1 is the most toxic of aflatoxins and, despite the fact that the carcinogenic and mutagenic effect of AFM1 is only $10 \%$ of AFB1 as it can enter the body in significant quantities with milk and dairy products, this derivative has also received a lot of attention lately.

If we are to prevent the AFM1 content of milk from being more than 50 $\mathrm{ng} / \mathrm{kg}$, which is already unsuitable for human consumption, the most important step is prevention, i.e. dairy animals must be fed with a high-quality feed, preferably free of mycotoxins. In Hungary, dairy cattle feed may contain a maximum of $5 \mu \mathrm{g} / \mathrm{kg}$ of AFB1, but the production of milk with a toxin content lower than allowed is still in doubt even in high-milk cows. It complicates the situation that the absorption of the toxin from feeding stuffs, in addition to the concentration of the toxin, is affected by the lactation status and microbial processes in the rumen as well as by the fact whether or not the 
toxin binder materials have been used in feeding.

AFM1 is extremely stable in milk, heat treatment and other technological processes have little effect on it, and it does not suffer significant decomposition during the production of dairy products. Although various physical, chemical, and microbiological methods have been tried to reduce the toxin content of milk, a major breakthrough in this area has not been achieved. Perhaps the most useful detoxification procedures appear to be when the reduction of the toxin content of dairy products has been achieved with microorganisms with a quality very similar to that of the cultures used in the production of dairy products. In summary, there is no procedure other than microbiological methods which can significantly reduce the toxin content of milk without significantly altering its nutritious value.

In addition to cow's milk, a significant amount of AFM1 can get into breast milk, such as in the previous cases, during the conversion of AFB1 to AFM1 in the mother's diet. In most European countries, one can either not detect toxins from breast milk at all or its amount is only a few nanograms per litre. The situation is much worse in African countries and in the Middle East, where $10-100 \%$ of breast milk were tested positive for AFM1, and the volume even exceeded levels of up to 200-1,000 ng/L. In the United States and the European Union, the maximum limit for the toxin content of breast milk is $25 \mathrm{ng} / \mathrm{L}$, which is significantly exceeded by the results of these other referred countries. It can be therefore said that in Europe the toxin exposure of infants to breast milk is negligible, while the situation may be critical for some African and Near East countries.

Very sensitive methods are available to determine the AFM1 content of milk. After proper preparation and concentration, most researchers use the HPLCMS and ELISA methods with the help of which even up to 10 nanograms of toxins can be detected. In addition to the very low detection level, the advantage of HPLC methods is that they allow the detection of several toxins from one sample. ELISA's popularity lies in the fact that, in addition to being very specific, it is extremely fast, and that several samples can be classified with it very quickly following proper preparations carried out even on site.

\section{Acknowledgements}

The work is supported by the EFOP-3.6.3-VEKOP-16-2017-00008 project. The project is co-financed by the European Union and the European Social Fund. We also gratefully acknowledge the support provided by Sapientia 
Hungarian University of Transylvania (Cluj-Napoca): Faculty of Economics, Socio-Human Sciences and Engineering (Miercurea Ciuc), Department of Food Science.

\section{References}

[1] Abdulrazzag, Y. M., Osman, N., Yousif, Z. M., Al-Falahi, S., Aflatoxin M1 in breast milk of UAE women. Annals of Tropical Paediatrics, 23. (2003) 173-179.

[2] Anfossi, L., Baggiani, C., Giovanoli, C., Biagioli, F., D’Arco, G., Giraudi, G., Optimization of lateral flow immunoassay for the ultrasensitive detection of aflatoxin M1 in milk. Analytica Chimica Acta, 772. (2013) 75-80.

[3] Bakirci, I., A study on the occurrence of aflatoxin M1 in milk and milk products produced in Van province of Turkey. Food Control, 12. (2001) $47-51$.

[4] Carraro, A., Giacomo, A. D., Giannossi, M. L., Medici, L., Muscarella, M., Palazzo, L., Clay minerals as adsorbents of aflatoxin M1 from contaminated milk and effect on milk quality. Applied Clay Science, 88-89. (2014) 92-99.

[5] Cattaneo, T. M. P., Marinoni, L., Iametti, S., Monti, L., Behaviour of aflatoxin M1 in dairy wastes subjected to different technological treatments: Ricotta cheese production, ultrafiltration and spray-drying. Food Control, 32. (2013) 77-82.

[6] Ciegler, A., Lillehoj, E. B., Peterson, R. B., Hall, H. H., Microbial detoxification of aflatoxin. Applied Microbiology, 14. 6. (1966) 934-939.

[7] Coulter, J. B. S., Lamplugh, S. M., Suliman, G. I., Omer, M. I. A., Hendrickse, R. G., Aflatoxin in human breast milk. Annals of Tropical Paediatrics, 4. (1984) 61-66.

[8] Creppy, E. E., Update of survey, regulation and toxic effects of mycotoxins in Europe. Toxicology Letters, 127. (2002) 19-28.

[9] Degen, G. H., Munoz, K., Hengstler, J. G., Occurrence of mycotoxins in breast milk. In: Zibadi, S., Watson, R. S., Preedy, V. R. (eds.), 
Handbook of dietary and nutritional aspects of human breast milk. Wageningen Academic Publishers, The Netherlands. (2013) 813-830.

[10] Diekman, D. A., Green, M. L., Mycotoxins and reproduction in domestic livestock. Journal of Animal Science, 70. (1992) 1615-1627.

[11] Doyle, M. P., Applebaum, R. S., Brackett, R. E., Marth, E. H., Physical, chemical and biological degradation of mycotoxins in foods and agricultural commodities. Journal of Food Protection, 45. 10. (1982) 964-971.

[12] Elsanhoty, R. M., Salam, S. A., Ramadan, M. F., Badr, F. H., Detoxification of aflatoxin $\mathrm{M} 1$ in yogurt using probiotic and lactic acid bacteria. Food Control, 43. (2014) 129-134.

[13] Fallah, A. A., Aflatoxin M1 contamination in dairy products marketed in Iran during winter and summer. Food Control, 21. (2010) 1478-1481.

[14] Fallah, A. A., Jafari, T., Fallah, A., Rahnama, M., Determination of aflatoxin M1 level in Iranian white and cream cheese. Food and Chemical Toxicology, 47. (2009) 1872-1875.

[15] Fisher, W. J., Schilter, B., Tritsher, A. M., Stadler, R. H., Environmental contaminants. Contaminants of milk and dairy products. In: Fuquay, J. W., Fox, P. F., McSweeney, P. L. H. (eds.), Encyclopedia of Dairy Science, $2^{\text {nd }}$ ed. Academic Press, London. (2011) 898-905.

[16] Fuchs, E., Bibder, E. M., Heidler, D., Krska, R., Structural characterisation of metabolites after the microbial degradation of A-trichotecenes by the bacterial strain BBSH 797. Food Additives and Contaminants, 19. (2002) 379-386.

[17] Galvano, F. et al., Molecular Nutrition and Food Research, 52. (2008) 496-501.

[18] Galvano, F., Galofaro, V., Galvano, G., Occurrence and stability of aflatoxin M1 in milk and milk products: A worldwide review. Journal of Food Protection, 59. (1996) 1079-1090.

[19] Govaris, A., Roussi, V., Koidis, P. A., Botsoglou, N. A., Distribution and stability of aflatoxin M1 during production and storage of yogurt. Food Additives and Contaminants, 19. 11. (2002) 1043-1050. 
[20] Guthrie, L. D., Effects of aflatoxin in corn on production and reproduction in dairy cattle. Journal of Dairy Science, 62. (1979) 134.

[21] Huang, L. C., Zheng, N., Zheng, B. Q., Wen, F., Cheng, J. B., Hang, R. W., Simultaneous determination of aflatoxin M1, ochratoxin A, zearalenon and $\alpha$-zearalenol in milk by UHPLC-MS/MS. Food Chemistry, 146. (2014) 242-249.

[22] Huwig, A., Freimund, S., Kappeli, O., Dutler, H., Mycotoxin detoxification of animal feed by different adsorbents. Toxicology Letters, 122. 2. (2001) 179-188.

[23] Hwang, J. H., Lee, K. G., Reduction of aflatoxin B1 contamination in wheat by various cooking treatments. Food Chemistry, 98. 1. (2006) $71-75$.

[24] Iqbal, S. Z., Jinap, S., Pirouz, A. A., Ahmad Faizal, A. R., Aflatoxin M1 in milk and dairy products, occurrence and recent challenges: A review. Trends in Food Science and Technology, 46. (2015) 110-119.

[25] Jalili, M., A review of aflatoxin reduction in food. Iranian Journal of Health, Safety and Environment, 3. 1. (2015) 445-459.

[26] Kabak, B., Ozbey, F., Aflatoxin M1 in UHT milk consumed in Turkey and first assessment of its bioaccessibility using an in vitro digestion model. Food Control, 28. (2012) 338-344.

[27] Khadem, A. A., Sharifi, S. D., Barati, M., Borji, M., Evaluation of the effectiveness of yeast, zeolite, and active charcoal as aflatoxin absorbents in broiler diets. Global Veterinaria, 8. 4. (2012) 426-432.

[28] Krska, R., Weizig, E., Berthiller, F., Molinelli, A., Mizaikoff, B., Advances in the analysis of mycotoxins and its quality assurance. Food Additives and Contaminants, 22. (2005) 345-353.

[29] Kumar, V. V., Aflatoxins: Properties, toxicity, and detoxification. $\mathrm{Nu}$ trition and Food Science, 6. 5. (2018) 1-4.

[30] Min, L., Li, D., Tong, X., Sun, H., Chen, W., Wang, G., Zheng, N., Wang, J., The challenges of global occurrence of aflatoxin M1 contamination and the reduction of aflatoxin M1 in milk over the past decade. Food Control, 117. (2020) 107352. 
[31] Nguyen, T., Flint, S., Palmer, J., Control of aflatoxin M1 in milk by novel methods: A review. Food Chemistry, 311. (2020) 125984.

[32] Oruc, H. H., Cibik, R., Yikmaz, R., Kalkanli, O., Distribution and stability of aflatoxin M1 during processing and ripening of traditional white pickled cheese. Food Additives and Contaminants, 23. (2006) 190195.

[33] Patterson, D. S. P., Anderson, P. H., Recent aflatoxin feeding experiments in cattle. Veterinary Research, 110. (1982) 60-61.

[34] Polychronaki, N., Mest, R. M., Turner, P. C., Amra, H., AbdelWahhab, M., Mykkanen, H., El-Nezami, H., A longitudinal assessment of aflatoxin M1 in breast milk of selected Egyptian mothers. Food and Chemical Toxicology, 45. (2017) 1210-1215.

[35] Prandini, A., Transini, G., Sigolo, S., Filippi, L., Laporta, M., Piva, G., On the occurrence of aflatoxin M1 in milk and dairy products. Food and Chemical Toxicology, 47. (2009) 984-991.

[36] Purchase, I. F. H., Acute toxicity of aflatoxin M1 and M2 in one-day-old ducklings. Food and Cosmetic Toxicology, 5. (1967). 339-342.

[37] Rasooly, A., Herold, K. E., Analytical methods. In: Fuquay, J. W., Fox, P. F., McSweeney, P. L. H. (eds.), Encyclopedia of Dairy Science, $2^{\text {nd }}$ ed. Academic Press, London. (2011) 284-296.

[38] Samarajeewa, U., Sen, A. C., Cohen, M. D., Wei, C. I., Detoxification of aflatoxins in foods and feeds by physical and chemical methods. Journal of Food Protection, 53. 6. (1990) 489-501.

[39] Santini, A., Ritieni, A., Aflatoxins: Risk, exposure and remediation. In: Razzaghi-Abyaneh, M. (ed.), Aflatoxins: Recent advances and future prospects. Tech Open, UK. (2013) 343-376.

[40] Serrano-Nino, J. C., Cavazos-Garduno, A., Hernandez-Mendoza, A., Applegate, B., Ferruzzi, M. G., Martin-Gonzales, M. F. S., Assessment of probiotic strains ability to reduce the bioaccessibility of aflatoxin M1 in artificially contaminated milk using an in vitro digestive model. Food Control, 31. (2013) 202-207.

[41] Shephard, G. S., Impact of mycotoxins on human health in developing countries. Food Additives and Contaminants, 25. 2. (2008) 146-151. 
[42] Sowley, E. N. K., Aflatoxins: A silent threat in developing countries. African Journal of Biotechnology, 159. (2016) 35.

[43] Spanjer, M. C., Occurrence \& risk of aflatoxin in food and feed. Netherlands Food and Consumer Product Safety Authority, Utrecht, The Netherlands. Elsevier. (2018) 1-5.

[44] Szeitzné Szabó, M., Frecskáné Csáki, K. (eds.), Az aflatoxin szennyezettség csökkentésének lehetőségei az élelmiszerláncban. A Nemzeti Élelmiszerlánc-biztonsági Hivatal (NÉBIH) Élelmiszerbiztonsági Kockázatértékelési Igazgatósága, a NÉBIH Élelmiszer- és Takarmánybiztonsági Igazgatósága, Növénytermesztési és Kertészeti Igazgatósága valamint Növény-, Talaj- és Agrárkörnyezet-védelmi Igazgatósága. (2013) 1-28.

[45] Sweeney, M. J., Dobson, A., Molecular biology of mycotoxin biosynthesis. Microbiology Letters, 175. 2. (1999) 149-163.

[46] Tabata, S., Aflatoxin contamination in foods and foodstuffs. Mycotoxins, 47. (1998) 9-14.

[47] Tadesse, S., Berhanu, T., Woldegiorgis, A. Z., Aflatoxin M1 in milk and milk products marketed by local and industrial producers in Bishoftu town of Ethiopia. Food Control, 118. (2020) 107386.

[48] Tejelö tehén takarmányok aflatoxin-szennyezettségének csökkentési lehetöségei. (2020).

Available at: https://portal.nebih.gov.hu/documents/10182/21392/ Tejelo_tehen_takarmanyok_aflatoxin_szennyezettsegenek_csokkentesi_ lehetosegei.pdf/84ae0f3c-88b4-48cb-9c08-973d888638fd.

[49] Tomerak, R. H., Shaban, H. H., Khalafallah, O. A., El Shazly, M. N., Assessment of exposure of Egyptian infants to aflatoxin M1 through breast milk. Journal of Egyptian Public Health Association, 86. (2011) $51-55$.

[50] Turconi, G., Guarcello, M., Livieri, C., Cimizzoli, S., Maccarini, I., Castellazzi, A., Pietri, A., Piva, G., Roggi, C., Evaluation of xenobiotics in human milk and ingestion by the newborn - An epidemiological survey in Lombardy (Northern Italy). European Journal of Nutrition, 43. (2004) 191-197. 
[51] Unusan, N., Occurrence of aflatoxin M1 in UHT milk in Turkey. Food and Chemical Toxicology, 44. 11. (2006) 1897-1900.

[52] Valenta, H., Chromatographic method for the determination of ochratoxin A in animal and human tissues and fluids. Journal of Chromatography A, 815. (1998) 75-92.

[53] Van Egmond, H. P., Aflatoxin M1: Occurrence, toxicity, regulation. In: Van Egmond, H. P. (ed.), Mycotoxins in dairy products. London: Publishers Elsevier Applied Science. (1989) 11-54.

[54] Wogan, G. M., Chemical nature and biological effects of the aflatoxins. Bacteriological Reviews, 30. 2. (1966) 360-370.

[55] Wogan, G. W., Paglialunga, S., Carcinogenicity of synthetic aflatoxin M1 in row milk from the Yangtze River Delta region of China. Food and Cosmetic Toxicology, 12. (1974) 381-384. 